\title{
Does Digital Media Literacy Influence Students' Perception of Hoax?
}

\author{
${ }^{1}$ Nur Octavi Mandasari, ${ }^{2}$ Primardiana Hermilia Wijayati, ${ }^{3}$ Rizman Usman \\ ${ }^{1,2,3}$ Faculty of Letters, State University of Malang, Malang, Indonesia \\ Email: ${ }^{1}$ octavye@ gmail.com, ${ }^{2}$ primardiana.hermilia.fs@ um.ac.id, \\ 3rizman.fs@um.ac.id
}

\begin{tabular}{l}
\hline Available Online: \\
\hline http://www.jurnal.unublitar.ac.id/ \\
index.php/briliant
\end{tabular}

History of the Article:

Received on 27 September 2020

Accepted on 8 February 2021

Published on 28 February 2021

Pages 11-20

\begin{tabular}{l}
\hline Keywords: \\
\hline Correlation; Literacy; Digital \\
Media; Hoax \\
\hline DOI: \\
\hline http://dx.doi.org/10.28926/briliant \\
.v3i4.557
\end{tabular}

\begin{abstract}
Abstrak: The purpose of this study was to find out whether there was the significant relationship between digital media literacy and students' perception of hoax. This research uses descriptive correlation methods with surveys as data collection. Respondents in this study were students of diploma, undergraduate, and graduate from 18 study programs at the Faculty of Letters, Universitas Negeri Malang. This study uses surveys conducted online using the Google Form website. The data were then analyzed by using Pearson's Product Moment Correlation in SPSS software. The results showed that there was a significant relationship between the level of digital media literacy and the perception of hoaxes, and it was in the moderate correlation. Based on the review of related literature, moderate correlation was occur due to several factors such as biased thinking, easily provoked age group, and difficulties in finding accurate media agencies.
\end{abstract}

\section{INTRODUCTION}

Based on the results of a survey conducted by Global Digital Insight, the number of internet users in Indonesia in 2020 amounted to 64,39\% (Tim GDI, 2020). It means that more than half of Indonesia's total population of 272,1 million people are people who are accustomed to accessing the internet using media digitally. In addition to the positive impacts caused, the progress of digital media and freedom of information also have a negative impact if its use is done unwise, one of the consequences is the spread of information hoaxes.

The Government, through the Ministry of Communication and Information, has made the Information and Electronic Transaction Law (UU ITE) which regulates the dissemination of hoax information. Based on the contents of article 28 paragraph 1 in the ITE Law, hoax information disseminators can be subject to a maximum sentence of six years and a maximum of 1 billion (Tim BIP, 2016). Even so, hoax information is still circulating freely, and it is even considering being at an alarming level (Figueira \& Oliveira, 2017). It shows that the perpetrators of hoax information dissemination did not heed the regulations in the ITE Law, causing the hoax to remain circulating in the middle of people's lives.

To control the spread of hoax information in the middle of the development of digital technology, Jones et al. (2019) expressed that someone 
who has the right level of literacy can identify hoax information. It means that someone who has a high level of literacy can distinguish between the correct information and hoax information. That way, the person naturally will be wiser in receiving information. For example, he will ensure and clarify the accuracy of the content before sharing information, and this has an impact on information hoaxes that will go down by themselves.

Paul Gilster first stated the concept of digital media literacy in 1997 in a book called Digital Literacy. Gilster defines digital media literacy as "literacy in the digital age" or the ability to understand and use various digital sources to obtain information (Mutka, 2011). Along with the times, Spante et al (2018) define digital media literacy as the ability to find, evaluate, understand, use, make information and utilize information from various digital media sources in a healthy, wise, intelligent, and law-abiding manner. Advances in digital media technology that make information easy to find, access, and use according to user needs are expected to be balanced with adequate media literacy. One's level of media literacy can be measured using the concept of the Individual Competence Framework. Individual competencies are a person's ability to use and utilize media, including the ability to use, produce, analyze, and communicate messages through media (Celot, 2015). Individual competence is divided into two categories, namely personal competence and communicative abilities. 1. Personal Competence, i.e. one's ability to use media and analyze media content. Personal competence consists of two criteria: a. Technical skills, namely technical abilities in using media. b. Critical Understanding, namely cognitive abilities in using media such as the ability to understand, analyze, and evaluate media content. 2 . Communicative Abilities, namely the ability to communicate and participate through the media. Communicative abilities include the ability to build social relations and participate in the community through the media. Someone has good communicative abilities if they can communicate correctly to build relationships on social media. These capabilities are for the Individual Competence Framework concept used by the Europan Commission in the Final Report Testing and Refining Criteria to Assess Media Literacy Level in Europe in 2011, to measure European Union society.

Ironically, Global World Digital Competitivness shows the level of Indonesian digital literacy is deficient compared to other countries in the world, which places Indonesia ranked 56 out of 63 countries surveyed (Tim IMD, 2020). The survey results show that literacy is a problem in the world of education in Indonesia that must be taken seriously. The hoax comes from the word hocus, which means deceiving or deceiving. According to the Indonesian Dictionary (KBBI), a hoax is a news that has no source or is also called hoax news. In general, hoax news is false news or stories that are made as if they were right.

This is following the statement, Finnerman\& Thomson (2018) defines hoax information as fabricated news and does not correspond to the real truth so that people receive information that is not under the facts that are spread through social media, websites, or public information. Therefore, it is not surprising that hoax information in Indonesia is difficult to reduce because the level of literacy is inversely proportional to media users, where digital media is currently used as an information center, while literacy is still very low.

12 BRILIANT: Jurnal Riset dan Konseptual Volume 6 Number 1, February 2021 
Furthermore, McDougal et al. (2018) stated, the concept of digital media literacy emerged along with the dominance of the media in the middle of social life that can quickly get and exchange information. Digital media literacy is used as demand as well as a guide in an increasingly rapid media civilization. Here the role of students who have critical and objective power is expected to be wise in using the internet to counter the circulation of hoax information ((El Rayess Maroun et al., 2018). Thus, students are expected to know qualified digital media literacy to be able to suppress the circulation of hoax information and become a useful example for others. Based on the background, the purpose of this study is to find out what is the relationship between the level of digital media literacy and the perception of hoax information on students.

\section{METHOD}

This research uses a descriptive correlation approach, with surveys as data collection techniques. Respondents in this study were 327 Diploma, Bachelor, and Master first-year students at the Faculty of Literature (FS) at the State University of Malang. The questionnaire (Likert Scale) as an instrument in this study was adapted from Simons et al. (2017) to measure the level of media literacy and Hussain (2018) about students' perceptions of hoax information. There are 12 items to measure the level of media literacy, including technical skills, critical understanding, and communicative abilities. Meanwhile, to measure students' perceptions of hoax information, 15 items are consisting of categories of concern for information, verifying information, and disseminating hoax information. Students are asked to provide answers to five choices, 5-Strongly Disagree, 4agree, 3-not sure, 2-disagree and 1-strongly disagree. Questionnaire data collection is done online using the Google Form website. Then the data were analyzed using SPSS software version 21 about Descriptive Statistics, Independent Sample T-Test, and Pearson's product-moment correlation.

\section{FINDINGS}

After surveying a research data collection technique in 18 study programs at the Faculty of Letters, Universitas Negeri Malang, the total respondents in this study were 327 students consisting of 21 Diploma students, 264 Bachelor students, and 42 Master students. Of the total 327 respondents, consisting of 100 male respondents $(30.5 \%)$ and 227 female respondents $(69.5 \%)$ and aged between 17-28 years.

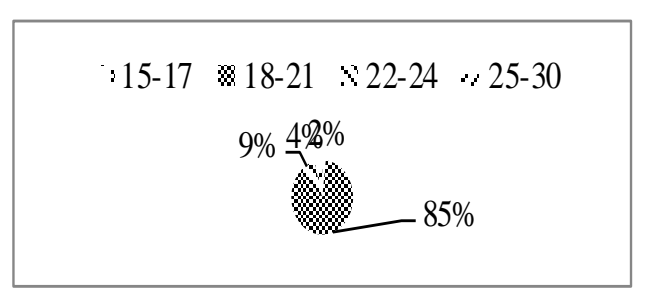

Fig. 1. Age of Respondents 
Figure 1 shows that most respondents aged 18-21 years, namely 279 respondents $(85 \%), 29$ respondents aged 22-24 years $(9 \%), 13$ respondents aged 25-30 years $4 \%$, and 6 respondents aged 15-17 years (2\%). D3 and S1 students are 17-21 years old, and S2 students are 22-28 years old.

Descriptive statistics questionnaire results from each category of two variables, namely the level of digital media literacy and students' perceptions of hoax information contained in table 1 and table 2.

Criteria for digital media literacy levels:

$3.5-5.0=$ Advanced; $2.5-3.4=$ Medium; $1.0-2.4=$ Basic

Criteria for perception of hoax information

$3.5-5.0=$ Frequently; $2.5-3.4=$ Medium; $1.0-2.4=$ Uncommon

\section{Digital Media Literacy Level}

The SPSS output on descriptive statistics on the results of the digital media literacy level consists of three categories, namely technical skills, critical understanding, and communicative abilities. Descriptive statistics output results consist of: Mean (M) is the average value calculated; the percentage (\%) shows the $\%$ of respondents who showed agreement with the questions given and the standard deviation (SD) was stated to be normally distributed if the SD results were less than $1(\mathrm{SD}<1)$.

Table 1. Descriptive Statistics Level of Digital Media Literacy

\begin{tabular}{|l|l|l|l|l|}
\hline \multicolumn{2}{|l|}{ Technical Skill } & M & SD & $\%$ \\
\hline 1 & Technically it can use media devices & 4,51 &, 695 & 90 \\
\hline 2 & $\begin{array}{l}\text { Can consciously choose and use different media } \\
\text { devices, based on their functions }\end{array}$ & 4,44 &, 698 & 88 \\
\hline 3 & $\begin{array}{l}\text { Can use various sources of information and media } \\
\text { devices according to their functions }\end{array}$ & 4,54 &, 658 & 90 \\
\hline Total & $\mathbf{4 , 5 0}$ & $\mathbf{, 6 1 3}$ & $\mathbf{9 0}$ \\
\hline Critical Understanding & & & \\
\hline 4 & Interpreting messages on media & 3,89 &, 828 & 77 \\
\hline 5 & $\begin{array}{l}\text { Knowing how the media are produced and } \\
\text { disseminated }\end{array}$ & 3,78 &, 727 & 75 \\
\hline 6 & $\begin{array}{l}\text { Knowing the media content produced according to } \\
\text { the target audience }\end{array}$ & 3,81 &, 805 & 76 \\
\hline 7 & $\begin{array}{l}\text { Evaluate media content by considering various } \\
\text { criteria }\end{array}$ & 3,80 &, 766 & 76 \\
\hline 8 & Be aware of the effects of media & 4,40 &, 733 & 88 \\
\hline 9 & Be aware of the dangers of unwise use of media & 4,10 &, 849 & 82 \\
\hline & Total & $\mathbf{3 , 9 6}$ & $\mathbf{, 5 4 2}$ & $\mathbf{7 9}$ \\
\hline Communicative Abilities & & & \\
\hline 10 & Create media content & 3,90 &, 852 & 78 \\
\hline 11 & Communicating and presenting content using media & 3,86 &, 832 & 77 \\
\hline 12 & Participate in public debates through the media & 3,55 &, 958 & 71 \\
\hline & Total & $\mathbf{3 , 7 7}$ & $\mathbf{7 1 3}$ & $\mathbf{7 5}$ \\
\hline & Digital Media Literacy Level & $\mathbf{4 , 0 5}$ & $\mathbf{, 4 9 9}$ & $\mathbf{8 1}$ \\
\hline
\end{tabular}

14 BRILIANT: Jurnal Riset dan Konseptual Volume 6 Number 1, February 2021 
Table 1 shows the level of digital media literacy and is in the advanced category, and the data distribution is normally distributed $(\mathrm{M}>3.50 ; \mathrm{SD}<1)$. This shows that $81 \%$ of respondents have technical skills, critical understanding, and communicative abilities in the advanced category.

\section{Perception of Hoax Information}

Perception items on hoax information are shown in table 2 which consists of three categories, namely trust in information, verifying information, and disseminating hoax information.

Table 2. Descriptive Statistics of Perception of Hoax Information

\begin{tabular}{|l|l|l|l|l|}
\hline \multicolumn{2}{|l|}{ Credibility of Information } & M & SD & $\%$ \\
\hline 1 & News content without sources may be incorrect & 4,24 &, 847 & 89 \\
\hline 2 & Some news is made to ruin someone's image & 3,65 & 1,001 & 73 \\
\hline 3 & Sometimes the news is presented in a misleading way & 3,96 &, 945 & 79 \\
\hline 4 & $\begin{array}{l}\text { Sometimes media agencies publish information that is not } \\
\text { verified to increase reader interest }\end{array}$ & 3,93 &, 857 & 78 \\
\hline 5 & $\begin{array}{l}\text { When the news doesn't match the headline, it might be } \\
\text { inaccurate }\end{array}$ & 3,88 &, 826 & 77 \\
\hline & Total & $\mathbf{3 , 9 3}$ & $\mathbf{, 6 4 0}$ & $\mathbf{7 8}$ \\
\hline Verifying Information & & & \\
\hline 6 & When in doubt, I check the source of the news content. & 4,20 &, 762 & 84 \\
\hline 7 & I always read news content, not just headlines & 4,05 &, 814 & 81 \\
\hline 8 & $\begin{array}{l}\text { I usually check the date of the news to make sure the news } \\
\text { is relevant and up to date }\end{array}$ & 4,00 &, 810 & 80 \\
\hline 9 & I checking the news in other media institutions & 3,89 &, 835 & 77 \\
\hline 10 & $\begin{array}{l}\text { I ask experts about the topics given to make sure the news } \\
\text { is true }\end{array}$ & 3,33 &, 880 & 66 \\
\hline & Total & $\mathbf{3 , 9 0}$ & $\mathbf{, 5 3 6}$ & $\mathbf{7 8}$ \\
\hline Spread hoax information & & & \\
\hline 11 & I think radiomay spread hoaxes & 2,96 &, 871 & 59 \\
\hline 12 & I think the newspaper may spread hoaxes & 3,07 &, 868 & 61 \\
\hline 13 & I think television spread may hoaxes & 3.34 &, 910 & 66 \\
\hline 14 & I think magazines may spread hoaxes & 3,20 &, 836 & 64 \\
\hline 15 & I think social media may spread hoaxes & 3.85 &, 990 & 77 \\
\hline & Total & $\mathbf{3 , 2 8}$ & $\mathbf{, 7 0 3}$ & $\mathbf{6 5}$ \\
\hline & Perception of Hoax Information & $\mathbf{4 2 3}$ & $\mathbf{7 4}$ \\
\hline
\end{tabular}

Table 2 shows the perception of hoax information is at frequent intensities $(\mathrm{M}=3.70 ; \mathrm{SD}<1)$ with $78 \%$ of respondents showing concern for information on the media, $78 \%$ verifying the information available on the media, and $65 \%$ of respondents assessing that the media is spreading hoax information.

\section{Analysis Results Based on Gender}

Table 3 shows the results of the questionnaire using the SPSS calculation on the Independence Sample T-Test to know the differences between genders (men and women). The significant probability of the difference is shown in: 
$(\mathrm{p}<.05)=$ there is a significant difference

$(p>.05)=$ there is no significant difference

The table shows that the level of digital media literacy in men totaling 100 respondents shows an advanced category $(\mathrm{M}=4.00 ; \mathrm{SD}<1)$ and 227 female respondents also indicate an advanced category $(M=4.07$; $S D<1)$. Significant results $(\mathrm{p})$ indicate that there is no significant difference between male and female respondents at the level of the category of digital literacy level $(p=327)$, where the data shows a significant difference when $(\mathrm{p})$ is less than $0.05(\mathrm{p}<.5)$.

Table 3. Independence Sample T-Test based on Gender

\begin{tabular}{|c|c|c|c|c|c|c|}
\hline & Gender & $\mathbf{N}$ & M & SD & df & $\mathbf{p}$ \\
\hline Digital & Male & 100 & 4,00 & ,576 & \multirow{2}{*}{325} & \multirow{2}{*}{,327 } \\
\hline Media Literac & Female & 227 & 4,07 & 459 & & \\
\hline \multirow{2}{*}{ Perception of Hoax } & Male & 100 & 3,68 & ,460 & \multirow{2}{*}{325} & \multirow{2}{*}{,416 } \\
\hline & Female & 227 & 3,72 & ,407 & & \\
\hline
\end{tabular}

The results on the perception of hoax information show that men have a perception of hoax information and are at moderate intensity $(\mathrm{M}=3.49 ; \mathrm{SD}=$ $0.367)$, while women are in the high category $(\mathrm{M}=3.68$; $\mathrm{SD}<1)$. However, the result (p) shows a score of more than $0.05(\mathrm{p}=.416)$, so it can be concluded that there are no significant differences between male and female respondents, both in the level of digital media literacy and perceptions of hoax information.

\section{Pearsons' Product Moment Correlation Analysis}

Table 4 is the output of SPSS about Pearsons' Product Moment Analysis of the correlation between the two variables, namely the level of digital media literacy and perspectives on hoax information. Guilford in "Fundamental Statistics in Psychology and Education" has several criteria.

These criteria are:

$(\mathrm{r}=.90-100)=$ very strong correlation

$(\mathrm{r}=.70-.90)=$ strong correlation

$(\mathrm{r}=.40-.70)=$ moderate correlation

$(\mathrm{r}=.20-.40)=$ weak correlation

$(\mathrm{r}=.00-.20)=$ very weak correlation

Based on these criteria, the output results indicate that there is a relationship between the two variables and are in the medium category $(r=0.462)$. Based on the results of table 4.4, according to the basis of Pearson's Product Moment decision making, the correlation is stated to be significantly related if it is less than $0.05(\mathrm{p}<.5)$. The significance value $(\mathrm{p})$ is 0.00 , meaning that there is a significant relationship between the two variables. The correlation results are in the medium category and show a positive value which means that there is a linear relationship between variables. This can be interpreted that some students who have high digital media literacy do not always have a perception of hoax information in the high category as well. 
Table 4. Pearsons' Product Moment Correlation

\begin{tabular}{|c|l|l|l|}
\hline \multicolumn{2}{|l|}{} & $\begin{array}{c}\text { Digital Media } \\
\text { literacy }\end{array}$ & $\begin{array}{c}\text { Perception of } \\
\text { Hoax }\end{array}$ \\
\hline Digital Media & Pearson Correlation & 1 &, $462^{* *}$ \\
Literacy & Sig. (2-tailed) & &, 000 \\
& N & 327 & 327 \\
\hline Perception of & Pearson Correlation &, $462^{* *}$ & 1 \\
Hoax & Sig. (2-tailed) &, 000 & \\
& N & 327 & 327 \\
\hline
\end{tabular}

The results of this study indicate that perceptions of the high intensity of students of the Faculty of Letters at the State University of Malang on hoax information do not always affect the level of literacy of their digital media. That is, students who are always checking, verifying, and assessing that media spreading hoaxes cannot always use digital media, are critically able to interpret messages on the media and can communicate messages to the media. This also applies oppositely, students who have low levels of digital media literacy do not always have a low perception of hoax information. As a result, students who have high digital media literacy can sometimes identify and sometimes also cannot identify hoax information.

\section{DISCUSSION}

Most of the students' program Diploma, Bachelor and Master at the Faculty of Letters at the Universitas Negeri Malang can use various media devices as sources of information, interpret messages on the media critically, and can communicate the messages that are on digital media. This is similar to the statement of Geisleer\& Horidge (2014) who examined students in Texas, US, and stated that students have adequate knowledge about the use of digital technology, and they have a high commitment to mastering various media. Moreover, there is no significant difference in the level of digital media literacy based on Gender (male and female) among students of Universitas Negeri Malang. This is following the statement of Mamedova \& Pawlowski (2018) which states "there is no measurable difference in digital literacy rates by gender" and rejects the stereotype which states that women have limited access to digital technology compared to men (Alliance for Women in Media Foundation, 2011). This explains that there is no difference in the level of literacy of digital media by Gender, and this can be explained from the results of Mamedova \& Pawlowski's research and this study.

The majority of respondents examine the information available in the media, check and ensure that the information received is valid, and assesses the media such as radio, newspapers, television, magazines, and social media to spread hoaxes. This is similar to the statement of Sterret et al. (2019) which states that American students do not believe in information in the media, especially social media because it is so easily manipulated that it potentially contains hoax information. This shows that students have high caution about the information in the media and are not readily consumed by the hoax.

Students who are always checking, verifying, and assessing that media spreading hoaxes cannot always use digital media, are critically able to interpret 
messages on the media and can communicate messages to the media. This also applies oppositely; students who have low levels of digital media literacy do not always have a low perception of hoax information. As result, students who have high digital media literacy can sometimes identify and sometimes also cannot identify hoax information. This can occur due to several factors such as thinking bias, young souls who are easily provoked, and the difficulty of getting accurate media agencies.

Rosenbaum \& Bonnet (2020) states that thinking bias is a human trait that is one of the reasons why a person cannot identify hoax information. These thinking biases include (1) bias of social proof; that is, someone tends to decide right what the group considers to be true. That is, someone tends to easily believe in information that is talked about and shared by many people, without checking the truth of the information. Then 2) confirmation bias, that is, someone tends to interpret the information by what is believed. That is, when getting information in the media, someone tends to select the information that is in line with his beliefs, while information that is not appropriate with beliefs, and then it is rejected. This causes a person cannot detect hoax information because what is believed is not necessarily true. Furthermore (3) availability bias that is, someone tends to create a picture of reality through examples or evidence that is best remembered. For example, when an area has just experienced an earthquake or tsunami, then when it is informed that an earthquake or tsunami will occur aftershocks the availability bias encourages someone to think that the area is not safe. This resulted in someone quickly receiving and sharing hoax information.

Therefore, it is crucial to improve the literacy skills of digital media so that students master the processing of information in the media so that even though thinking bias is human nature, students are expected to be able to reason without easily following the flow of information that is not necessarily valid. The statement was mainly shown to first-year students, aged less than 20 years, also called Net Generation, in which they are proficient in technology. Net Generation's expertise in using and operating digital technology can have a negative effect because they are a group of teenagers who are easily provoked by information, so they quickly spread information that is being viral without verifying the truth first (Dirga \& Wijayati, 2018; Kovacs, 2020). While graduate students are included in the adult category, and they are more able to control emotions, so they are not easily provoked by hoax information. Besides, there are currently several fact-checking features or services available to evaluate the credibility of online news sources. In essence, students as a net generation are expected not to be passive and activate reasoning thinking by first testing and validating the information received before forwarding or redistributing information.

Evaluating the credibility of the media is important because currently, it is difficult to get an accurate media institution (Molina et al., 2019). This can be interpreted in the digital era that it is difficult to find media institutions that do not support a particular ideology or political position in conveying information. However, the position of media institutions is believed to remain an important part of conveying information. In the ease of the Net Generation in obtaining information from various digital media, media institutions are expected to remain present in providing complete information in fact because the misguided and

18 BRILIANT: Jurnal Riset dan Konseptual Volume 6 Number 1, February 2021 
unclear information received can make social situations out of control. Therefore, the provisioning of digital media literacy to students who are the Net Generation needs to be done. There is a higher chance of students getting lost on access to information if they are not equipped with digital media literacy. Knowledge of digital media literacy can ensure that the information obtained is not only correct, but also intact, or not fragmented, not misleading, and in context. A critical attitude in finding and trusting information is expected to suppress hoax information.

\section{CONCLUSION}

Most of the students of diploma, undergraduate, and graduate programs at the Faculty of Letters, Universitas Negeri Malang can use various media devices as sources of information, interpret messages on the media critically, and can communicate the messages that are on digital media. Then there is no significant difference in the level of digital media literacy based on Gender (male and female) among students. It means that male and female students have the same level of digital media literacy, which is at a high level. Furthermore, there is a significant relationship between the level of digital media literacy and the perception of hoax information. In other words, the hypothesis (H1) in this study was accepted. The correlation level is in the medium category which means that some students who have a literacy level of digital media in the advanced category do not always have a perception that is in the high category of hoax information. This can occur due to several factors such as thinking bias, youth who are easily provoked, and the difficulty of getting accurate media institutions.

\section{SUGGESTION}

Amid the abundance of information and knowledge at this time, students as the net generation and have qualified digital literacy can be involved in efforts to reduce hoax information that is spread in the community. Moreover, researchers hope that further research will cover a wider range, not only the Net generation but also the previous generation (Y generation), which from several studies stated that $\mathrm{Y}$ generation is the generation that most spreads hoax information.

\section{REFERENCES}

Alliance for Women in Media Foundation. (2011). Special Report on Digital Literacy for Women and Girls. McLean.

Celot, P. (2015). Assessing Media Literacy Levels and the European Commission Pilot Initiative. European Association for Viewers Interest.

Dirga, R. N., \& Wijayati, P. H. (2018). How can teachers assess reading skills of generation $z$ learners in German language class? The 4th Consortium of Asia Pacific Education University (CAPEU) International Conference on Science, Technology, Engineering, and Marhematics (STEM) "Innovatiuon for Human talents."

El Rayess Maroun, Chebl Charla, Mhanna Joseph, \& Hage Re-Mi. (2018). Fake news judgement: The case of undergraduate students at Notre Dame University-Louaize, Lebanon. Reference Services Review, 46(1), 146-149. https://doi.org/10.1108/RSR-07-2017-0027 
Figueira, Á., \& Oliveira, L. (2017). The current state of fake news: Challenges and opportunities. Procedia Computer Science, 121, 817-825. https://doi.org/10.1016/j.procs.2017.11.106

Finneman, T., \& Thomas, R. J. (2018). A family of falsehoods: Deception, media hoaxes and fake news. Newspaper Research Journal, 39(3), 350-361. https://doi.org/10.1177/0739532918796228

Geisleer, J., \& Horidge, P. (2014). University Students' Computer Knowledge and Commitment to Learning. Journal of Research in Computing in Education, 25(3), 347-365.

Hussain, A. E. (2018). A Journal of the Pacific and Asian Communication Association, 1(2), 1-21.

Jones-Jang, S. M., Mortensen, T., \& Liu, J. (2019). Does Media Literacy Help Identification of Fake News? Information Literacy Helps, but Other Literacies Don't. American Behavioral Scientist, 000276421986940. https://doi.org/10.1177/0002764219869406

Kovacs, K. (2020, June 4). Gen Z has a misinformation problem. Digital Content Next. $\quad$ https://digitalcontentnext.org/blog/2020/06/04/gen-z-has-amisinformation-problem/

Mamedova, S., \& Pawlowski, E. (2018). A Description of U.S. Adults Who Are Not Digitally Literate. Statistics in Brief.

McDougall, J., Readman, M., \& Wilkinson, P. (2018). The uses of (digital) literacy. Learning, Media and Technology, 43(3), 263-279. https://doi.org/10.1080/17439884.2018.1462206

Molina, M. D., Sundar, S. S., Le, T., \& Lee, D. (2019). "Fake News" Is Not Simply False Information: A Concept Explication and Taxonomy of Online Content. American Behavioral Scientist, 0002764219878224. https://doi.org/10.1177/0002764219878224

Mutka, K. A. (2011). Mapping Digital Competence: Toward Conseptual Understanding.

Rosenbaum, J., \& Bonnet, J. (2020). Looking inward in an era of 'fake news': Addressing cognitive bias. Young Leader of the Americans Initiative. https://ylai.state.gov/

Simons, M., Meeus, W., \& T'Sas, J. (2017). Measuring Media Literacy for Media Education: Development of a Questionnaire for Teachers' Competencies. Journal of Media Literacy Education, 9(1).

Spante, M., Sofkova Hashemi, S., Lundin, M., \& Algers, A. (2018). Digital competence and digital literacy in higher education research: Systematic review of concept use. Cogent Education, 5. https://doi.org/10.1080/2331186X.2018.1519143

Sterrett, D., Malato, D., Benz, J., Kantor, L., Tompson, T., Rosenstiel, T., Sonderman, J., \& Loker, K. (2019). Who Shared It?: Deciding What News to Trust on Social Media. Digital Journalism, 7(6), 783-801. https://doi.org/10.1080/21670811.2019.1623702

Tim BIP. (2016). Undang-Undang Informasi dan Transaksi Elektronik (Jakarta Pusat). Bhuana Ilmu Populer.

Tim GDI. (2020). Global Digital Insight. datareportal.com

Tim IMD. (2020). IMD World Digital Competitiveness Ranking 2020 result [IMD Excecutive Education]. WorldCompetitiveness Center. http://imd.org 